\title{
Arts and crafts as an educational strategy and coping mechanism for Republic of Korea and United States parents during the COVID-19 pandemic
}

\author{
Meera Choi ${ }^{1}$ (D) Hannah Tessler ${ }^{1} \cdot$ Grace Kao $^{1}$
}

Accepted: 9 October 2020 / Published online: 23 October 2020

(c) UNESCO Institute for Lifelong Learning and Springer Nature B.V. 2020

\begin{abstract}
The COVID-19 pandemic and ensuing stay-at-home orders have shifted family lives worldwide. Government regulations about social distancing and isolation have resulted in parents/carers and children spending most of their time together in private spaces. During the northern hemisphere spring 2020 semester, most childcare and school systems closed and parents had to dramatically modify their balance between work and home life. Using data from consumer reports, online parenting forums and blog posts, and Google Trends, the authors of this article explored how some parents have shifted towards cultural and creative enrichment as a resource to occupy their children during governmental stay-at-home directives in both the United States and the Republic of Korea. The authors found that arts and crafts and educational toy sales have increased, parents are sharing advice and resources for athome creative activities, and arts and cultural institutions have expanded their free online content. Finally, this article discusses whether the short-term stressors from COVID-19 might lead to long-term changes in parenting and sustained interest in these resources. The authors' findings provide additional support for the importance of arts and humanities in the educational experience of children.
\end{abstract}

Keywords arts and crafts · arts education - creative experience $\cdot$ parenting strategy COVID-19

Meera Choi

meera.choi@yale.edu

Hannah Tessler

hannah.tessler@yale.edu

Grace Kao

g.kao@yale.edu

1 Department of Sociology, Yale University, New Haven, CT, USA 


\section{Résumé}

Les activités artistiques et artisanales, une stratégie éducative et d'adaptation pour les parents en République de Corée et aux États-Unis pendant la pandémie de COVID-19 - La pandémie de COVID-19 et les ordres de confinement qu'elle a entraînés ont bouleversé la vie des familles dans le monde entier. Du fait des mesures de distanciation physique et d'isolement prises par les gouvernements, les enfants et les parents/les personnes chargées de s'occuper d'eux ont passé la majeure partie du temps ensemble, dans des espaces privés. Pendant le printemps 2020 de l'hémisphère nord, la plupart des services de garde d'enfants et des établissements scolaires ont fermé, et les parents ont dû modifier considérablement l'équilibre travail-famille. En s'appuyant sur des informations recueillies dans des rapports sur les consommateurs, dans des forums en ligne et des billets publiés dans des blogs sur la parentalité, et sur une analyse des tendances de Google Trends, les auteures de cet article ont examiné comment certains parents ont fait de l'enrichissement culturel et créatif une ressource pour occuper leurs enfants durant le confinement ordonné par les gouvernements aux États-Unis et en Corée. Elles ont constaté que les ventes de jouets créatifs et éducatifs avaient augmenté, que les parents partageaient des conseils et des ressources pour faire des activités d'art et d'artisanat à la maison, et que les établissements artistiques et culturels proposaient davantage de contenus gratuits. Enfin, l'article se demande si les facteurs de stress à court terme dus à la COVID-19 pourraient provoquer des changements à long terme en ce qui concerne la parentalité et créer un intérêt durable pour ces ressources. Les résultats des recherches menées par les auteures sont des éléments de plus qui étayent l'importance des arts et des sciences humaines dans l'éducation des enfants.

\section{Introduction}

The COVID-19 pandemic has transformed the dynamics of family life worldwide. In early March 2020, as COVID-19 cases steadily increased in the United States (US), state directives urged people to stay at home, resulting in more than 42 states closing schools and enforcing stay-at-home orders (Mervosh et al. 2020). By the end of the 2019/2020 academic year, 47 states had instituted some period of school closure (Nagel 2020). Consequently, 55.1 million pupils in $K-12$ education $^{1}$ stayed at home during some part of the northern hemisphere spring 2020 semester (Peele and Riser-Kositsky 2020). Government regulations about social distancing and school closures have resulted in parents/carers and children spending most of their time together in private spaces. Parents have needed to develop multi-tasking strategies as they work for their employers and care for their children. In addition, parents may feel an extra burden to both promote continued learning outside the classroom and keep their children occupied.

\footnotetext{
${ }^{1}$ K-12 refers to education spanning Kindergarten to Grade 12 (the last year of secondary/high school in the US).
} 
The Republic of Korea (henceforth referred to as Korea) experienced a surge in COVID-19 cases earlier than the US, with more than 900 cases per day in late February 2020 (Illmer 2020). All schools were closed from Korean winter break to May 2020, and some schools remained closed through Korean summer 2020. However, the Korean government did not issue strict stay-at-home orders, and only about 40 per cent of companies in Korea implemented a remote work system (KBS World Radio 2020). Compared to an almost complete lockdown of businesses in the US, the economic sector in Korea remained fairly open, with government recommendations for social distancing in place.

While the extent of COVID-19's impact on the US and Korea has been different, parents in both countries have experienced the burden of having to manage their children's schedules and health conditions full-time. Simultaneously, parents have had to provide supplementary educational enrichment activities so their children could keep up with online learning.

In this article, we explore the extent to which school closures in the US and Korea may have promoted particular types of parent-child activities above others. Specifically, we examine how parents have increasingly turned to arts and crafts or, more broadly, cultural activities, as these pursuits address two pressing needs. The research questions we set out to investigate were:

(1) Because parents sometimes multi-task and need to find occupations to fill their children's time, to what extent are they interested in activities that require greater concentration and focus on the part of their children?

(2) As the physical separation between school and home has disappeared, do parents feel more pressure to find activities that can be justified as having some educational merit?

In other words, have the activities parents have undertaken with their children during COVID-19 shifted in a fundamental way?

We argue that while school closures in the US and Korea occurred at roughly the same time, there are some differences between the two countries in terms of how the stress of COVID-19 has been felt by parents and children. In the US, based on data from the American Community Survey, ${ }^{2}$ just over a quarter (26\%) of children under the age of 18 live in single-parent households (Pew Research Center 2015). At the same time, data from the Current Population Survey ${ }^{3}$ show that while 18 per cent of children under the age of 18 live in a household with one stay-at-home parent and one working parent, the majority of children in the US live in households where both parents are in the paid labour force (Cohn et al. 2014).

\footnotetext{
2 The American Community Survey (ACS) is an ongoing survey conducted by the US Census Bureau. It provides information on a yearly basis about the US and its people. The data generated by this survey help affect how federal and state funds are distributed each year.

3 The Current Population Survey (CPS), also administered by the US Census Bureau, collects information on a monthly basis from a probability-selected sample of households to compile labour force statistics for the population of the United States.
} 
By contrast, in Korea only 7 per cent of children under the age of 18 live in single-parent households (KOSIS 2017). Among two-parent households in Korea, 50 per cent of children live in a household with a stay-at-home mother and a working father, while 50 per cent live in a household where both parents work (ibid.).

These demographic differences in family structure suggest that parents may face distinct challenges in managing their children's time and activities during the COVID-19 crisis. Single-parent households and dual-income households may find it particularly difficult to balance their work and family life. In both the US and Korea, differences in socio-economic status also play a role in how parents approach their children's development. Based on existing research, we argue that socio-economic status is another important dimension to consider in analysing parenting strategies in the context of COVID-19. In the study we present in this article, we compare the cases of the US and Korea to evaluate how the timing and impact of COVID-19, as well as access to creative opportunities, might influence children's educational experiences despite the disruptions to formal, in-person school and day care (childcare) ${ }^{4}$ attendance.

\section{Challenges to family life during COVID-19}

Since the outbreak of the COVID-19 pandemic, media outlets have reported on the unprecedented challenges to parenting and the work-life balance among adults. Parents have struggled to arrange new schedules, inform their children about the pandemic and support them both emotionally and psychologically (Cerretani 2020). COVID-19 has brought new challenges to parent-child interactions, with parents simultaneously serving as primary caregivers and educators of their children.

Children have faced particular difficulties as schools and childcare facilities have been shut down or gone out of business. Particularly for young children, dramatic shifts in everyday routines are major stressors that may lead to psychological distress (Moroni et al. 2020). Youth no longer have access to group activities, playgrounds, "playdates" 5 or extracurricular activities that once occupied much of their time. Moreover, they are also feeling the general sense of loss and anxiety that adults are experiencing during the current pandemic (CDC 2020). At the same time, students have shifted to online learning and are no longer spending significant time with their peers in classroom environments (Burgess and Sievertsen 2020; Moroni et al. 2020; Wang et al. 2020).

While all children's lives have been affected by the school closures, children from low socio-economic backgrounds are at greater risk of suffering from the negative consequences of being out of school. These include, but are not limited to, nutritional deficiency (Balingit 2020), child abuse (Cao and Sandner 2020; Humphreys

\footnotetext{
${ }^{4}$ Day care or childcare is a service provided to care for young children under school age during the day, for example while their parents are at work.

5 A playdate is an arranged time for children from different families to play together outside of a childcare or school setting; it is a commonly used term in the US.
} 
et al. 2020), and developmental and educational setbacks (Burgess and Sievertsen 2020). According to a Pew Research Center survey, after the shift to online schooling due to COVID-19, about 76 per cent of low-income parents in the US responded that they were concerned about their children potentially falling behind in their education (Horowitz 2020). Consistent with these concerns, one report on educational disruptions during COVID-19 found that only 44 per cent of school districts in the US were both providing online instructions and monitoring students' engagement (Hill 2020). Most of these schools were located in low-income neighbourhoods, where parents were more likely to be classified as "essential workers", 6 and hence did not have the option to work from home (ibid.).

Low-income parents are facing economic hardships due to job loss, and potential safety concerns if they are still in their job, since they are more likely to be engaged in essential work which cannot be carried out from home. More than 90 per cent of low-income jobs in 2017 and 2018 could not be done remotely (Gould and Shierholz 2020), which suggests that low-income parents may be at greater risk of exposure to COVID-19 by having to be at their workplace in person. Moreover, about half of lower-income adults in the US have reported that they or someone in their household lost their job or experienced a decrease in wages during the pandemic (Parker et al. 2020). In addition to the economic uncertainty and safety risks, these parents face a greater burden fulfilling childcare responsibilities than parents with higher socio-economic status, since they have to worry about keeping their children safe. Low-income parents, therefore, may have neither enough resources nor the time to engage in their children's education and daily routines, and the added stress may result in harsher parenting (Choi 2020).

The challenges families face in the time of COVID-19 have potentially negative consequences for their psychological well-being. Moreover, there is the risk of widening the gap of educational inequality among children from different socio-economic backgrounds. While we believe that these are important concerns, we also argue that for some children, there may be an increase in creative opportunities as a result of changes in parenting strategies and family time. In a series of surveys conducted by Save the Children (Save the Children 2020a), ${ }^{7} 72$ per cent of children responded that they were looking forward to spending more time with their families and 61 per cent of parents felt positively about taking on more responsibility in regard to their children's schoolwork (Save the Children 2020b). Having more time together as a family, along with changes in parent-child interactions, may have some long-term positive effects on children.

\footnotetext{
${ }^{6}$ Essential workers are people whose jobs are deemed to be essential to the functioning of society. Examples are supermarket employees, especially till operators, community care workers, public transport operators, waste disposal employees etc.

7 "Save the Children Child Protection staff conducted phone-based and online surveys to determine the effects of the social restrictions on children in the United States (1,500 parents and children), Spain (2,000 households), UK (1,002 parents), Finland (1,121 children and youth), Germany (1,002 parents and children), Nicaragua (60 children) and Indonesia (68 children), in March and April 2020" (Save the Children 2020a).
} 
In our study, we specifically focused on increased opportunities for creative pursuits during the pandemic in the US and Korea. The availability of cultural activities has increased during the pandemic, since cultural institutions (such as museums, galleries and other educational entities) have adjusted to social distancing guidelines. Hence, these institutions now offer additional and often free online opportunities for people to enjoy exhibitions and tours from home. Based on our analysis of consumer behaviour data, online parenting forums and blog posts, and Google Trends, we found that in both countries, parents with access to the internet and free time were looking for time-consuming arts and crafts activities and virtual learning events for children. Some parents were also actively sharing information online about how to spend time with children, as they focused on enhancing parent-child relationships at home, despite the adverse circumstances.

However, it is important to be aware that some children may benefit more from these additional arts-related opportunities than others, since younger children often rely on their parents to set up and facilitate engagement in these activities. Therefore, later in this article we discuss the implications of unequal opportunities. We also suggest that institutions and communities can engage more actively in supporting children during the pandemic, which would help to alleviate the burden on individuals trying to balance parenting and work during this time.

Before we launch into an account of our study, it is useful to consider what parent-child interaction was like before the onset of the pandemic and the shifts this exceptional situation has led to.

\section{Parent-child interaction and parenting strategies before COVID-19}

Parenting strategies and time spent with children are issues of long-standing interest to scholars investigating the fields of education and family. The interactions and relationships between parents and their children play an important role in nurturing the growth of children's cognitive ability, transferring educational expectations and encouraging educational achievement (Bianchi and Robinson 1997; Villena-Roldan and Ríos-Aguilar 2012). Parents' investment in time spent with their children and the types of activities they engage in have been understood as a pathway to gaining

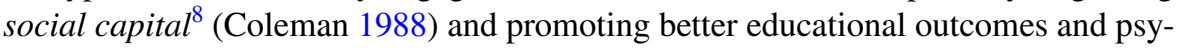
chological well-being (Bono et al. 2016; Fontainha 2014; Offer 2013).

Scholars have argued that the types of joint activities families engage in are as important for children's development as the amount of time they spend together (Crouter et al. 2004; Larson and Richards 1994). Parental time includes a variety of activities, such as recreational (non-sport playing, sport playing, engaging in arts and crafts), routine basic care (direct physical care of children) and educational

\footnotetext{
${ }^{8}$ French philosopher Pierre Bourdieu distinguishes between three main types of capital (assets). They are economic capital (e.g. money, property); social capital (e.g. a network of friends, colleagues etc.); and cultural capital (e.g. education). The latter two are potentially "convertible, on certain conditions, into economic capital" (Bourdieu 1986, p. 243)
} 
activities (helping or teaching children, reading with children) (Guryan et al. 2008; Kalil et al. 2012; Musick et al. 2016). Some research even suggests that parental time spent interacting with children through educational and recreational activities provides the greatest benefit to children (Bianchi 2000; Fiorini and Keane 2015; Milkie et al. 2015).

\section{Total childcare time per day}

In the US, 2018 American Time Use Survey ${ }^{9}$ data show that mothers of children under the age of six spent an average of 169 minutes per day on total childcare, including 5 minutes on reading activities, 43 minutes on playing and 7 minutes on educational activities. Fathers with children under the age of six spent an average of 78 minutes per day on total childcare activities. Out of the total time, fathers spent 2 minutes reading to and with children, 28 minutes on playing with children and 3 minutes on educational activities (U.S. Bureau of Labor Statistics 2018).

In Korea, the patterns in time use are similar. According to 2009 Time Diary Data, ${ }^{10}$ mothers of children at preschool age or younger spent an average of 198 minutes per day on childcare, which included 21 minutes on reading and 41 minutes on playing with children. Fathers of children at preschool age or younger spent an average of 52 minutes per day on childcare, which included 4 minutes on reading and 25 minutes on playing with children (Song 2011).

However, in both countries there are socio-economic status-related differences in how parents spend time with their children. Pre-pandemic research suggests that, in the US, higher-educated parents spend more time with their children, with an average difference of 4.5 hours per day between college (university) graduate mothers and mothers with high school degrees or less (Guryan et al. 2008).

Similarly, in Korea, parental socio-economic status is positively correlated with childcare time (Song 2011). Highly educated Korean parents with preschoolers spend more time playing with and providing physical care to children compared to their less-educated counterparts (ibid.). Higher-educated Korean parents with school-age children spend more time helping with children's schoolwork compared to less-educated parents (ibid.).

\section{Types of parent-child activities}

The types of activities parents engage in with children in the US also differ by parents' socio-economic status (Bianchi et al. 2006). Highly educated parents engage in more enriching activities and invest in different pursuits based on their children's

\footnotetext{
${ }^{9}$ The American Time Use Survey (ATUS) is conducted by the US Census Bureau and is linked to the Current Population Survey (CPS). ATUS measures the amount of time American people spend doing various activities, such as paid work, childcare, caring for elderly family members, volunteering, socialising etc.

10 The Korean Time Diary Data survey is conducted by Statistics Korea (KOSTAT). Like ATUS it collects information about how people spend their time.
} 
developmental needs (Kalil et al. 2012). In addition, as Annette Lareau and many other scholars have found, parents from higher socio-economic backgrounds put significantly more effort into managing their children's personal development and extracurricular activities, whereas parents from lower socio-economic backgrounds try to meet their children's basic material needs while giving their children more autonomy over their leisure time (Lareau 2003).

In addition, research suggests that children's engagement and participation in arts and creative activities, such as visiting art galleries and attending operas or concerts, has a positive effect on their academic achievement (DiMaggio 1982; DiMaggio and Mohr 1985), academic motivation, school engagement, personal self-esteem and life satisfaction (Martin et al. 2013). Another American study, based on the Early Childhood Longitudinal Study Kindergarten cohort (ECLS-K: 1998-1999), ${ }^{11}$ shows that children who visited museums in their early childhood attained higher reading, mathematics and science scores at school (Swan 2014). Moreover, there is also evidence suggesting that early exposure to arts by visiting art museums motivates children to acquire creative thinking skills and develop new cultural capital ${ }^{12}$ (Greene et al. 2014a, 2014b; Kisida et al. 2016; Kisida et al. 2014).

However, opportunities to participate in the arts are not readily available to all children. Not only are there geographic limits to accessing these types of experiences, but exposure to arts institutions also varies based on families' socio-economic status and ethnicity. Specifically, children from historically underprivileged backgrounds are less likely to have opportunities to participate in these experiences. According to scholars of cultural capital and social stratification, ${ }^{13}$ arts exposure through visits to museums and exhibitions varies by social class, with children from high socio-economic backgrounds participating in these experiences at higher rates than their counterparts from lower socio-economic backgrounds (Chan and Goldthorpe 2007; DiMaggio and Ostrower 1990; DiMaggio and Useem 1978). Through art experiences, children acquire "cultural taste", which translates into cultural capital. The possession of cultural capital plays an important role in gaining educational credentials (qualifications) and increases the likelihood of having higher educational attainment (Kalmijn and Kraaykamp 1996; Katsillis and Rubinson 1990; Sullivan 2001). Given how exposure to arts institutions may lead to higher educational achievement, increased opportunities for accessing artistic and cultural experiences online may play a role in reducing educational gaps between high and low socio-economic status children.

\footnotetext{
11 The Early Childhood Longitudinal Studies (ECLS) programme is run by the Institute of Education Sciences, National Center for Education Statistics (IES-NCES), based in Washington, DC.

12 Cultural capital it the third of Bourdieu's (1986) main types of capital; see footnote 8.

13 Social stratification refers to categorising people into groups based on socio-economic factors such as wealth, income and education.
} 


\section{Disruption of established patterns by the onset of the COVID-19 pandemic}

To sum up, the amount of time parents spend with their children, and the types of activities they engage in, differ by parents' socio-economic status and family structure in the US and Korea. However, COVID-19 has disrupted normal time-use patterns because parents are now responsible for full-time childcare in addition to their jobs. Managing work and childcare at the same time is even more difficult now, particularly for low-income parents who are essential workers. Nonetheless, parents must somehow find and implement strategies that accommodate a difficult work-family balance while providing their children with a nurturing environment.

Presenting our own investigation into the impact of the pandemic in the next section, we turn to how some parents' consumption patterns for and activities with their children have changed since the start of COVID-19.

\section{Method}

To address our research questions (see introductory section), we analysed three different types of data and compared how behaviour has shifted in both the US and Korea, including: (1) consumer report data; (2) online parenting forums and blog posts; and (3) Google Trends data. Our research team consisted of the three authors of this article, and we selected our data sources based on our interest in capturing the aggregate trends in behaviour during the COVID-19 pandemic. We found secondary data sources through two internet search engines, Google and Naver, which we consulted from 22 April to 20 June 2020. To collect information on the general trends of parenting strategies during COVID-19, we used a variety of keywords including "COVID-19 parenting," "COVID-19 parent-child relationship," "COVID19 arts and crafts," "COVID-19 museum tours," and "COVID-19 arts education". We established a Google alert ${ }^{14}$ on these keywords to incorporate new contents posted during the research period.

We found consumer trends on toys and arts and crafts kits in reports compiled by market research companies such as the NPD Group and Statista. We also found relevant information in newspaper articles. We gathered more information on how parents exchange parenting ideas by looking at online forums. We searched for the same keywords mentioned above in the largest online "mom community" in Korea, Mamseuholig. ${ }^{15}$ We also searched for keywords in Reddit's "parenting" subreddits. ${ }^{16}$ Finally, we consulted Google Trends, which provides information on the number of

\footnotetext{
${ }^{14}$ Google alert (https://www.google.com/alerts) is a tool to receive notifications about new contents posted on the internet on a certain topic.

15 Mamseuholig ["Mom's Holic"] (https://cafe.naver.com/imsanbu) is the largest online mom community in South Korea where mostly mothers share ideas, information, and concerns about parenting. The online community has almost 3 million members.

16 Reddit is a US-American online forum where members can post content and interact with each other on discussion boards. Members can also upvote and downvote the content other people post, so the most popular posts are prominent on the forum's homepage.
} 
searches of certain keywords in the search engine, summarising data from searches worldwide to show the overall popularity of search terms. Other researchers have noted that Google Trends can be a good data source to analyse media attention and search interests (Rech 2007).

\section{Arts and crafts and educational toy consumption as a parenting strategy during COVID-19}

As a result of the COVID-19 pandemic and stay-at-home mandates, toy sales surged in both the US and Korea (Fickenscher 2020; Nam 2020). In the US, overall toy sales in the first quarter of 2020 rose by 26 per cent compared to the same period in the previous year (NPD 2020). Reports indicate that the critical driver of growth was the closure of schools in March (ibid.). Toys that led the boost in sales were games and puzzles, building sets, and arts and crafts kits - with an increase of 228 per cent, 76 per cent and 70 per cent respectively (ibid.). In addition, sales of educational resources and non-fiction books increased by 66 per cent, including general activity books (128\%), study aids (235\%), and language arts and handwriting books (265\%) (ibid.). Colouring and art supplies - including chalk, window/glass markers, colour markers and finger paints - also had an increased sales volume (86\%) (ibid.).

In Korea, toy sales for toddlers and young children increased substantially in the first week of February 2020, with reports showing sales up to 360 per cent higher than during a typical week (Statista 2020). The main drivers of growth were educational toys such as calculator toys $(367 \%)$, as well as ball tents $(285 \%),{ }^{17}$ cars and airplanes $(116 \%)$, slides $(111 \%)$, toy blocks $(106 \%)$ and toy craft kits (86\%) (ibid.). Multiple online shopping vendors also reported that during the peak of COVID-19 infections in Korea, demand for toys for toddlers and young children soared, mostly centred on large toys such as slides and jungle gyms (Nam 2020; Oh 2020). ${ }^{18}$ Other popular categories among Korean parents were kitchen sets, board games and educational books (Oh 2020). This evidence suggests that parents in both the US and Korea have shifted their attention to toys that keep their children busy and occupied.

In online parenting forums and blogs, parents in both countries have been actively sharing tips and information about engaging their children during their time at home with free or cost-effective supplies. Most of the suggestions we found were related to activities that take little time to prepare but occupy plenty of children's time while also promoting creativity. Naver, the most popular online search engine in Korea, started an idea competition for parents titled "Stuck-At-Home Activities with Children: Mothers' Wisdom to Overcome COVID-19”. In just one month (March 2020), more than 500 ideas were posted (Lee 2020). As the title of the competition suggests, most of the information was shared by and with mothers in Korea. People

\footnotetext{
17 A ball tent is a foldable tent-shaped structure, the floor of which is surrounded by a border to keep in a thick layer of plastic balls, among which toddlers can take a "ball bath".

18 A jungle gym, sometimes also referred to as monkey bars, is a climbing frame, usually permanently set up in a playground.
} 
used "Mom's Ideas" as the common hashtag when they shared ideas for creative activities with children.

\section{Increased opportunities to experience art and culture and access to virtual museums and virtual live theatres}

Another emerging pattern we found is the increase in opportunities for children to engage in cultural and arts-related experiences through open-entrance policies in virtual museums, art galleries and live performances for children. This may provide an additional coping strategy for parents seeking to schedule productive and educational time for their children when they cannot be in school or day care. As many countries practised social distancing and/or issued stay-at-home orders during the pandemic, many arts and cultural institutions also shut down temporarily. As a result, major national museums and art galleries expanded their online content. Simultaneously, parents and teachers sought additional educational activities for their children and students (Finney 2020).

Parenting blogs and websites recommended free online museum tours globally, including The Louvre in Paris, France; the Uffizi Gallery in Florence, Italy; The British Museum in London, England; and the US National Gallery of Art in Washington, DC. Given that these online museum tours are accessible to everyone with an internet connection, regardless of geographic location, they provide opportunities for children in both the US and Korea (the focus of our investigation) to engage with art. In Korea, the National Museum of Korea, and art galleries such as the Seoul Museum of Art, the SAVINA Museum (also in Seoul) and the Datz Museum of Art (in Gyeonggi-do) also opened online exhibitions with curators as a response to school closures. Museums may also provide relief from the psychosocial distress of COVID-19; in Korea, this is referred to as "coronablue". Another source of relief may be cinemas. The South Korean government provided the Busan Cinema Centre with over 200 million Korean won's worth of funding to run online arts education programmes for children and adolescents (Heo 2020).

In the online environment, children from both the US and Korea (and many other countries) ${ }^{19}$ can climb a virtual Mount Everest via Google, walk around the Great Wall of China or even explore the surface of Mars (Finney 2020; Jones 2020). Young people can join a live safari at Cincinnati Zoo through Facebook Live (Finney 2020) and observe animal behaviour closely by accessing animal webcams ${ }^{20}$ in the Smithsonian's National Zoo in Washington, DC for free. Theatrical productions and performing arts centres offer free activities and pop-up classrooms for parents and

\footnotetext{
${ }^{19}$ Korean newspaper articles also featured opportunities to attend online tours for world famous museums and art galleries.

20 A webcam is a video camera (placed, for instance, in a field or a wood) that streams video recordings to the internet.
} 
students (Silver 2020). There are also numerous virtual summer camps ${ }^{21}$ offered for free (Mills 2020).

Figure 1 presents data from US-based Google searches for virtual museums or related tours from June 2019 to June 2020. Google examines users' interest in these searches over a pre-specified time period and assigns a score of 100 for the period of peak interest, and a score of 50 for half of the level of interest at the peak. Starting in mid-March 2020, people's interest in "virtual museums tours for kids", "virtual zoo tours for kids" and "virtual field trips for kids" increased dramatically. According to Google Trends, people in the US expressed little interest in these virtual experiences until the beginning of the pandemic. Interest in virtual museums and zoo tours peaked at the end of March 2020. Parents demonstrated a continued interest in online field trips and virtual activities even through the third week of June 2020.

In Korea, Galleries Art Fair 2020, an annual event celebrating its 38th anniversary this year, opened both online and offline exhibitions during COVID-19. The gallery reported 15,000 online visitors in five days, which is 2,000 visitors more than the number who typically attended the fair in person in previous years (Kim 2020). More than 14,000 people participated in a free online live tour with a curator at the National Museum of Modern and Contemporary Art (MMCA) in Seoul. In three weeks, over 50,000 people streamed the video of the online tour. More than 3,000 people streamed an Instagram live show with a curator of another exhibition at MMCA (Kang 2020)

To sum up, based on our review of consumer reports and online parenting discussion forums, we identified several changes in parents' behaviour since the beginning of the COVID-19 pandemic. We found that parents in both the US and Korea seemed to encourage their children to engage in creative endeavours as a strategy to occupy their time and attention as well as provide some educational value. First, parents have increased their purchase volume/consumption of arts and crafts-related toys and merchandise. They have also participated in online discussions about activities that parents and children can do together. Second, parents have been sharing information about virtual events and summer camps. Moreover, cultural institutions have been expanding their offerings of virtual tours and programmes. Finally, there are now more resources online than before the onset of the pandemic that offer free creative opportunities for children that may help them develop educational and creative skills.

However, we posit that children are not benefitting equally from these additional resources and online opportunities, as there are likely socio-economic differences in the amount of time and money parents are able to dedicate to their children during the pandemic. In addition, COVID-19 has impacted the US and Korea differently, as shutdowns have been more complete and longer-lasting in the US than in Korea. Moreover, there have been many more cases of COVID-19 in the US than in Korea.

Next, we analyse the potential implications of these observed changes in both the US and Korean contexts.

\footnotetext{
21 Summer camps are programmes for children and/or teenagers conducted during the summer months in some countries; they usually involve educational, sports or cultural activities.
} 


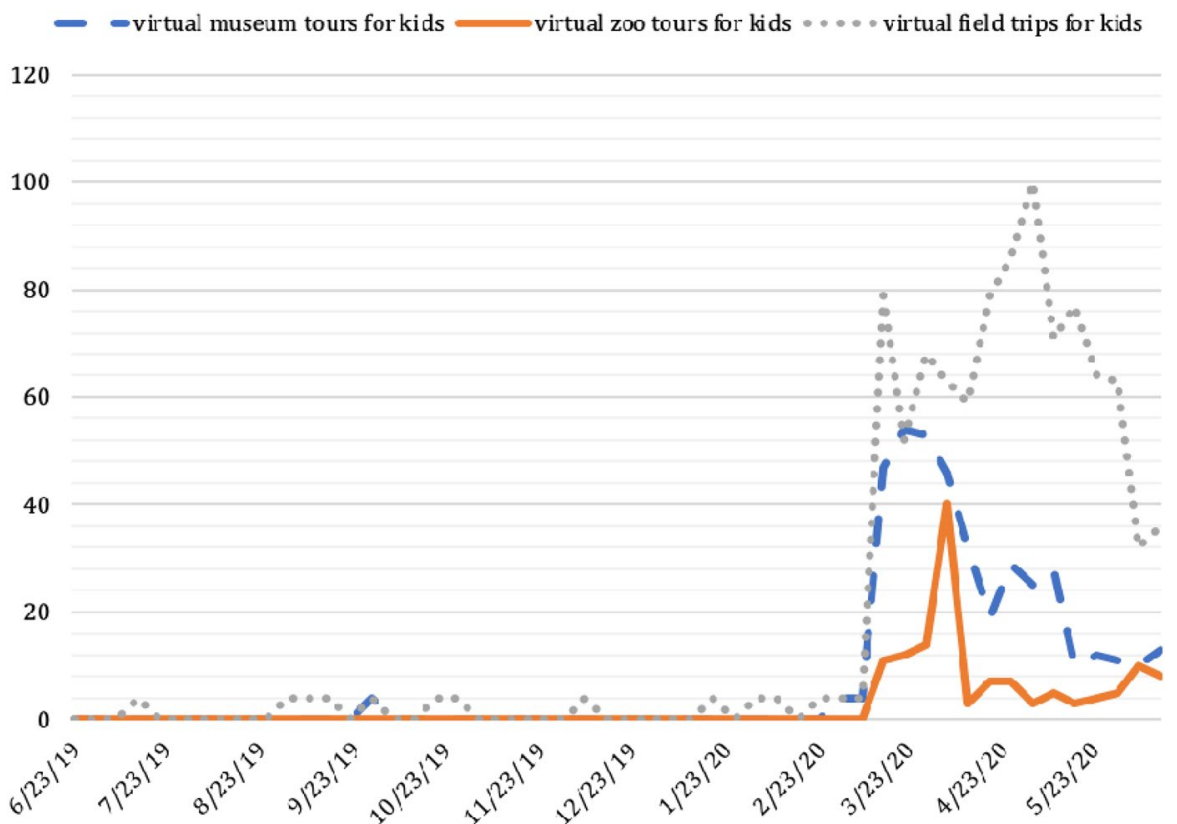

Fig. 1 Peak interest in Google searches for virtual cultural activities in the US during COVID-19 by date: June 2019-June 2020. Source: Google (2020)

\section{Opportunities and threats of the new parenting strategies on children's development and well-being}

Thus far, we have identified increasing cultural and creative activities for children during COVID-19. If these activities are sustained beyond the COVID-19 crisis, this would represent a significant shift in how children spend their free time. Some scholars suggest that arts and crafts activities foster creativity among a wide range of students (Coholic and Eys 2016; Root-Bernstein 2015). One study of high-achieving college (university) graduates showed that STEM majors ${ }^{22}$ who had more arts and crafts experiences than their peers exhibited better creative skills. These experiences were significantly associated with entrepreneurship and patentable inventions (LaMore et al. 2013). Moreover, research has shown that arts and crafts are beneficial for resilience and positive self-concept development among children who have experienced abuse, loss, trauma and other challenges (Coholic and Eys 2016). Given that the COVID-19 pandemic may traumatise children in a number of ways, increased participation in creative activities may promote resilience and lead children to better psychosocial health. ${ }^{23}$ Previous research suggests that creative activities in everyday life are positively associated with improved coping strategies for

22 STEM majors are students who specialise in science, technology, engineering and mathematics.

23 Psychosocial health refers to various mental, emotional and social dimensions of health. 
young children, especially during adverse childhood experiences such as the recent quarantines and lockdowns (Verger et al. 2020).

Virtual openings of cultural institutions and facilities such as museums, libraries and art galleries have brought new opportunities for children to engage in cultural and art activities. Before the COVID-19 pandemic, the geographical locations of these institutions gave greater access to families from higher socio-economic status backgrounds who could afford the cost and time to travel. Thus, the majority of children were not able to cultivate cultural capital and knowledge as they did not have access to these spaces. However, as stay-at-home orders prohibited people from visiting these cultural institutions in person, the institutions began to offer exhibitions online and provide virtual experiences to the public for free. Consequently, children from all over the world can now access high quality arts and monuments through digital devices. In this regard, the expansion of opportunities to participate in cultural and art activities not only helps children's educational development, but it also reveals the possibility that expanded access may help to mitigate socio-economic status differences in cultural knowledge.

Although access to these sources has increased, it may be difficult for children to seek out or participate in these activities without parental guidance. Parents from high socio-economic backgrounds are more likely to manage children's time and provide resources to promote continued learning and creativity-building through arts and crafts than parents with lower socio-economic status. By contrast, parents from lower socio-economic backgrounds face more severe economic instability during the pandemic. As a result, they have fewer economic resources and, perhaps more importantly, less time to invest in children's arts and crafts activities. At the same time, the consequences of the digital divide among people who own digital devices and have access to reliable high-speed internet and those who do not are greater during the pandemic than before, as much of life has moved online. We suspect that these differences have exacerbated inequalities in learning. Even though many resources are available online, utilising these resources still requires an internet connection, a digital device and, depending on the age of the child, parental supervision and help.

We suggest that institutions and organisations could promote creative activities as a cost-efficient way to engage children from low socio-economic status backgrounds. Korea serves as a case study to demonstrate how providing additional resources for children during the pandemic may bring about larger social benefits. In Korea, most local governments implemented drive-through or walk-through toy rental systems in an attempt to reduce parental stress and burden. The Korean government also provided a subsidy card credited with about USD 80 to 1.61 million low-income individuals to promote their participation in cultural and art activities.

Moreover, many English-language and Korean online blogs and forums offer ideas for low-budget arts and crafts activities, for example, using paper-towel tubes and other household leftovers. With cooperation and help from local communities and childcare professionals, children from more disadvantaged backgrounds can access these necessary educational and developmental aids. Children can participate in arts and crafts activities at no cost, and they can develop important psychosocial skills such as resilience, emotional regulation and creative problem-solving 
to overcome the challenges they face. These additional opportunities could potentially help to mitigate the pandemic's unequal educational and mental health consequences among children.

While our article focuses on the well-being of children, we know that parents are also under great stress during this time of instability. Even if their jobs and financial situations are secure, parents are clearly at risk of burnout and exhaustion from continuous child-rearing responsibilities (Mikolajczak et al. 2018). We believe that additional resources and support from educational institutions, creative organisations and local governments can benefit both parents and children, and support children's educational development. We hope that both the US and Korea will become better equipped to weather the sustained time that parents and children may have to spend together during future stay-at-home orders.

This study has broader implications for cultural and educational policies, since we draw attention to the value of arts and humanities beyond direct labour market returns. We argue that creative experiences are essential for psychosocial development and well-being. These activities help children develop skills and coping strategies such as creativity, resilience and problem-solving, especially during prolonged traumatic experiences. Our study proposes that supporting arts and creative experiences at home is a fundamental way to keep children engaged in distance learning and provide outlets for them to express their emotions and relieve stress. There is evidence that arts and humanities education is under threat, and that higher education institutions' priorities have shifted away from liberal arts education and towards majors (academic specialisations) and programmes that are seen to have direct labour market returns (Duffy 2020).

In the US, funding for the arts is in peril as budget reductions by many states threaten children's education. This is particularly the case during these tumultuous COVID-19 times. For example, school districts in Massachusetts have already laid off art, music and physical education teachers and have entirely removed funding for programmes related to these fields for the coming school year in 2020/2021 (McCalliss 2020). Numerous public and private universities ${ }^{24}$ in the US have already announced that they are reducing funding for liberal arts and humanities programmes in response to the budget deficits faced during the COVID-19 crisis (Dickler 2020). In Philadelphia, the mayor eliminated the entire budget for the Office of Arts, Culture and the Creative Economy in 2020/2021 and all funding for the Philadelphia Cultural Fund (Salisbury 2020).

Similarly, in Korea, budgets for arts and humanities majors are the first to be reduced or eliminated in universities when there is a financial crisis (Yun 2013). University students majoring in arts-related fields have continuously problematised the Ministry of Education's project to "kill fine art" (Park 2020). Continuous debates about whether it is fair to support professional and amateur artists with the taxes of the general public suggest that not all citizens believe in the value of art. In general, the Korean government has increased its budget for culture and the arts

\footnotetext{
${ }^{24}$ In the US, public universities are subsidised by the state while private universities are funded by private tuition and contributions.
} 
since 2005; however, the budget is mostly used to support the virtual reality content sector to boost the economy (Anderson 2019). The government's funding for arts and humanities still shows a narrow understanding of the value of art that is limited to its direct economic impact.

Arguably, humanities education should also be valued based on its social benefits and not just its direct labour market outcomes. Instead, arts and humanities education should be understood as being strongly connected to creativity, resilience and problem-solving (Nussbaum 2010). For example, Lisanne Gibson (2008) suggests that museums' and galleries' objectives include education, entertainment, social inclusion and community regeneration. She argues that arts are means to achieve these objectives, but they are also fundamentally intrinsic core values of the arts. Robert Hewinson and John Holden (2004), in their cultural values framework for the Heritage Lottery Fund, ${ }^{25}$ suggest that learning, individual well-being and community prosperity are fundamental benefits of arts and humanities programmes and institutions. We hope that the insights provided both by earlier research and in the evidence we found in our own study of increased popularity and importance to families of arts and humanities during the current pandemic will prompt policymakers to value arts and humanities institutions in preparation for the post-COVID-19 era.

Acknowledgements We gratefully acknowledge support from the Faculty of Arts and Sciences, the MacMillan Center, and the Council for East Asia at Yale University. We are also grateful for the support of the Laboratory Program for Korean Studies through the Ministry of Education of the Republic of Korea and the Korean Studies Promotion Service of the Academy of Korean Studies (AKS-2016-LAB-2250002).

\section{References}

Anderson, A. (2019). South Korea gets record-breaking culture budget. International Arts Manager, 19 December [webnews]. Retrieved 10 July 2020 from http://www.internationalartsmanager.com/news/ arts/south-korea-gets-record-breaking-culture-budget.html.

Balingit, M. (2020). Schools serve more than 20 million free lunches every day. If they close, where will children eat? Washington Post, 16 March [online article]. Retrieved 20 June 2020 from https://www. washingtonpost.com/local/education/schools-serve-more-than-20-million-free-lunches-every-dayif-they-close-where-will-children-eat/2020/03/16/29c4f35a-655e-11ea-845d-e35b0234b136_story .html.

Bianchi, S. M. (2000). Maternal employment and time with children: Dramatic change or surprising continuity? Demography, 37(4), 401-414. https://doi.org/10.1353/dem.2000.0001.

Bianchi, S. M., \& Robinson, J. (1997). What did you do today? Children's use of time, family composition, and the acquisition of social capital. Journal of Marriage and Family, 59(2), 332-344. https:// doi.org/10.2307/353474.

Bianchi, S. M., Robinson, J. P., \& Milke, M. A. (2006). The changing rhythms of American family life. New York, N.Y.: Russell Sage Foundation.

Bono, E. D., Francesconi, M., Kelly, Y., \& Sacker, A. (2016). Early maternal time investment and early child outcomes. The Economic Journal, 126(596), F96-F135. https://doi.org/10.1111/ecoj.12342.

Bourdieu, P. (1986). The forms of capital. In J. G. Richardson (Ed.), Handbook of theory and research for the sociology of education (pp. 241-259). New York: Greenwood Press.

\footnotetext{
${ }^{25}$ Using money raised through the United Kingdom's National Lottery, the Heritage Lottery Fund (HLF) provides grants to sustain and transform national heritage. These grants support museums, parks, historic sites, archaeological projects, natural environment projects and cultural traditions.
} 
Burgess, S., \& Sievertsen, H.H. (2020). Schools, skills, and learning: The impact of COVID-19 on education. VoxEU, 1 April [online article]. London: VoxEU, policy portal of the Centre for Economic Policy Research (CEPR). Retrieved 9 June 2020 from https://voxeu.org/article/impact-covid-19education.

Cao, E.D., \& Sandner, M. (2020). The potential impact of the COVID-19 on child abuse and neglect: The role of childcare and unemployment. VoxEU, 8 May [online article]. London: VoxEU, policy portal of the Centre for Economic Policy Research (CEPR). Retrieved 20 June 2020 from https://voxeu .org/article/potential-impact-covid-19-child-abuse-and-neglect.

CDC (Centers for Disease Control and Prevention) (2020). Coronavirus disease 2019 (COVID-19): Coping with stress. $C P C$ website, 11 February [dedicated webpage]. Atlanta, GA: Centers for Disease Control and Prevention. Retrieved 20 June 2020 from https://www.cdc.gov/coronavirus/2019-ncov/ daily-life-coping/managing-stress-anxiety.html.

Cerretani, J. (2020). Parenting in the age of COVID-19: Coping with six common challenges. Boston Children's Hospital Discoveries webpage, 17 April [online advice]. Boston, MA: Boston Children's Hospital. Retrieved 20 June 2020 from https://discoveries.childrenshospital.org/covid-parentingchallenges/.

Chan, T. W., \& Goldthorpe, J. H. (2007). Social stratification and cultural consumption: Music in England. European Sociological Review, 23(1), 1-19. https://doi.org/10.1093/esr/jc1016.

Choi, K.H. (2020). COVID-19 \& parenting challenges. Psychology Today, 21 May [blog post]. Retrieved 2 September 2020 from https:/www.psychologytoday.com/blog/social-fabric/202005/covid-19parenting-challenges.

Cohn, D., Livingston, G., \& Wang, W. (2014). Stay-at-home mothers on the rise. Pew Research Center Social \& Demographic Trends, 8 April [online article]. Washington, DC: Pew Research Center. Retrieved 20 June 2020 from https://www.pewsocialtrends.org/2014/04/08/after-decades-of-declinea-rise-in-stay-at-home-mothers/.

Coholic, D. A., \& Eys, M. (2016). Benefits of an arts-based mindfulness group intervention for vulnerable children. Child and Adolescent Social Work Journal, 33(1), 1-13. https://doi.org/10.1007/s1056 0-015-0431-3.

Coleman, J. S. (1988). Social capital in the creation of human capital. American Journal of Sociology, 94, S95-S120. https://doi.org/10.1086/228943.

Crouter, A. C., Head, M. R., Mchale, S. M., \& Tucker, C. J. (2004). Family time and the psychosocial adjustment of adolescent siblings and their parents. Journal of Marriage and Family, 66(1), 147162. https://doi.org/10.1111/j.0022-2445.2004.00010.x-i1.

Dickler, J. (2020). Colleges cut academic programs in the face of budget shortfalls due to COVID-19. Consumer News and Business Channel $(C N B C), 23$ June [online news item]. Englewood Cliffs, NJ: CNBC. Retrieved 10 July 2020 from https://www.cnbc.com/2020/06/23/colleges-cut-programs-inface-of-budget-shortfalls-due-to-covid-19.html.

DiMaggio, P. (1982). Cultural capital and school success: The impact of status culture participation on the grades of US high school students. American Sociological Review, 47(2), 189-201. https://doi. org/10.2307/2094962.

DiMaggio, P., \& Mohr, J. (1985). Cultural capital, educational attainment, and marital selection. American Journal of Sociology, 90(6), 1231-1261. https://doi.org/10.1086/228209.

DiMaggio, P., \& Ostrower, F. (1990). Participation in the arts by black and white Americans. Social Forces, 68(3), 753-778. https://doi.org/10.1093/sf/68.3.753.

DiMaggio, P., \& Useem, M. (1978). Social class and arts consumption. Theory and Society, 5(2), 141161. https://doi.org/10.1007/BF01702159.

Duffy, C. (2020). Humanities degrees to double in cost as government funnels students into "job-relevant" uni courses. ABC News, 18 June [online news item]. Retrieved 10 July 2020 from https:// www.abc.net.au/news/2020-06-19/university-fees-tertiary-education-overhaul-course-costs/12367 742.

Fickenscher, L. (2020). Toy sales surge as Coronavirus pandemic keeps kids home. New York Post. 30 March [online article]. Retrieved dd month 2020 from https://nypost.com/2020/03/30/toy-sales -surge-as-coronavirus-pandemic-keeps-kids-home/.

Finney, M. (2020). Coronavirus impact: Consumer reports' free online activities, virtual museum tours for children during COVID-19 pandemic. ABC7 San Francisco, 2 April [online news item]. Retrieved 20 June 2020 from https://abc7news.com/6069762/.

Fiorini, M., \& Keane, M. P. (2015). How the allocation of children's time affects cognitive and noncognitive development. Journal of Labor Economics, 32(4), 787-836. https://doi.org/10.1086/677232. 
Fontainha, E. (2014). Parental time and child well-being. In A. C. Michalos (Ed.), Encyclopedia of quality of life and well-being research (pp. 4596-4600). Dordrecht: Springer. https://doi. org/10.1007/978-94-007-0753-5_2069.

Gibson, L. (2008). defence of instrumentality. Cultural Trends, 17(4), 247-257. https://doi. org/10.1080/09548960802615380.

Google (2020). Interest over time: Virtual museum tours for kids/virtual zoo tours for kids/virtual field trips for kids. Google Trends [online database]. Retrieved 9 June 2020 from https://trends.googl e.com/trends/explore?geo=US\&q=virtual\%20museum $\% 20$ tours $\% 20$ for $\% 20 \mathrm{kids}$, virtual $\% 20 \mathrm{zoo}$ $\% 20$ tours $\% 20$ for $\% 20$ kids, virtual $\% 20$ field $\% 20$ trips $\% 20$ for $\% 20$ kids.

Gould, E., \& Shierholz, H. (2020). Not everybody can work from home: Black and Hispanic workers are much less likely to be able to telework. Working Economics Blog, 19 March [blog post]. Washington, DC: Economic Policy Institute (EPI). Retrieved 2 September 2020 from https://www.epi.org/ blog/black-and-hispanic-workers-are-much-less-likely-to-be-able-to-work-from-home/.

Greene, J. P., Kisida, B., \& Bowen, D. H. (2014a). The benefits of culturally enriching field trips. Education Digest, 79(8), 4-13.

Greene, J. P., Kisida, B., \& Bowen, D. H. (2014b). The educational value of field trips. Education Next, 14(1), 78-86.

Guryan, J., Hurst, E., \& Kearney, M. (2008). Parental education and parental time with children. Journal of Economic Perspectives, 22(3), 23-46. www.aeaweb.org/articles?id=10.1257/jep.22.3.23.

Heo, S. (2020). 영화의전당, 포스트 코로나 '운화예술교육'으로 대비 [Cinema centre prepares for post-Corona culture and arts education]. Newsis, 1 May [online news item]. Retrieved from https:// www.newsis.com/view/?id=NISX20200501_0001011628.

Hewinson, R., \& Holden, J. (2004). Challence and change: HLF and cultural value. A report to the Heritage Lottery Fund. London: Demos. Retrieved 10 September 2020 from https://www.heritagefu nd.org.uk/sites/default/files/media/research/challengeandchange_culturalvalue.pdf.

Hill, P.T. (2020). During COVID-19, Underperforming school districts have no excuse for standstill on student learning. Brown Center Chalkboard, 6 May [blog post]. Washington, DC: The Brookings Institution. Retrieved 9 June 2020 from https://www.brookings.edu/blog/brown-center-chalkboard /2020/05/06/during-covid-19-underperforming-school-districts-have-no-excuse-for-standstill-onstudent-learning/.

Horowitz, J.M. (2020). Lower-income parents most concerned about their children falling behind amid COVID-19 school closures. Pew Research Center Fact Tank, 15 April [online article]. Washington, DC: Pew Research Center. Retrieved 20 June 2020 from https://www.pewresearch.org/facttank/2020/04/15/lower-income-parents-most-concerned-about-their-children-falling-behind-amidcovid-19-school-closures/.

Humphreys, K.L., Myint, M.T., \& Zeanah, C.H. (2020). Increased risk for family violence during the COVID-19 pandemic. Pediatrics, 146(1), Art. e20200982. https://doi.org/10.1542/peds.2020-0982.

Illmer, A. (2020). Why did virus infections skyrocket in South Korea? BBC News, 25 February [online news item]. Retrieved 20 June 2020 from https://www.bbc.com/news/world-asia-51609840.

Jones, D. (2020). 12 historic sites you can virtually tour from the couch during the Coronavirus outbreak. Washington Post, 18 March [online news item]. Retrieved 20 June 2020 from https://www.washi ngtonpost.com/trave1/2020/03/18/these-historic-sites-attractions-are-offering-virtual-tours-durin g-coronavirus-pandemic/.

Kalil, A., Ryan, R., \& Corey, M. (2012). Diverging destinies: Maternal education and the developmental gradient in time with children. Demography, 49(4), 1361-1383. https://doi.org/10.1007/s1352 4-012-0129-5.

Kalmijn, M., \& Kraaykamp, G. (1996). Race, cultural capital, and schooling: An analysis of trends in the United States. Sociology of Education, 69(1), 22-34. https://doi.org/10.2307/2112721.

Kang, J. (2020). 코로나 19 대처 호평 국립현대미술관, '온라 인미술관, 개설 [National Museum of Contemporary Art acclaimed for coping well with COVID-19, opened "online museum"]. Yonhap News, 22 April [online news item]. Retrieved 20 June 2020 from https://www.yna.co.kr/view/ AKR20200422063800005.

Katsillis, J., \& Rubinson, R. (1990). Cultural capital, student achievement, and educational reproduction: The case of Greece. American Sociological Review, 55(2), 270-279. https://doi.org/10.2307/20956 32.

KBS World Radio (2020). COVID-19 outbreak puts "smart work" to the test. KBS World Radio, 23 March [online news item]. Retrieved 20 June 2020 from http://world.kbs.co.kr/service/contents_ view.htm?lang=e\&menu_cate=business\&board_seq=381752. 
Kim, C. (2020). 코로나 19 직격탄 맞 은 2020 화랑미술제, 절실했던 현실에 대처하며 무사히 폐막 [Galleries Art Fair 2020, hit by the COVID-19, ended safely in coping with the desperate reality]. Asia Arts, 24 February [online news item]. Retrieved 20 June 2020 from http://www.asiaarts.net/ view.php?ud=202002240231186199f6c6bd0e60_38

Kisida, B., Bowen, D. H., \& Greene, J. P. (2016). Measuring critical thinking: Results from an art museum field trip experiment. Journal of Research on Educational Effectiveness, 9(sup1), 171-187. https://doi.org/10.1080/19345747.2015.1086915.

Kisida, B., Greene, J. P., \& Bowen, D. H. (2014). Creating cultural consumers: The dynamics of cultural capital acquisition. Sociology of Education, 87(4), 281-295. https://doi.org/10.1177/0038040714 549076.

KOSIS (Korean Statistical Information Service) (2017). 한부모 가구 비율 [Percentage of single parent families]. e-Country Index [online database]. Daejeon: Korean Statistical Information Service. Retrieved 20 June 2020 from http://www.index.go.kr/potal/main/EachDtlPageDeta il.do?idx_cd=1578.

LaMore, R., Root-Bernstein, R., Root-Bernstein, M., Schweitzer, J. H., Lawton, J. L., Roraback, E., et al. (2013). Arts and crafts: Critical to economic innovation. Economic Development Quarterly, 27(3), 221-229. https://doi.org/10.1177/0891242413486186.

Lareau, A. (2003). Unequal childhoods: Class, race, and family life. Berkeley, CA: University of California Press.

Larson, R., \& Richards, M. H. (1994). Divergent realities: The emotional lives of mothers, fathers, and adolescents. New York, NY: BasicBooks.

Lee, J. (2020). 코로나 19 이기는 엄마의 지혜...네이버 '부모i판' “집콕놀이' 사연 500여건 쌓여 [Mother's wisdom to cope with COVID-19, "stay-at-home play" over 500 stories posted in Naver "Parent section (i-Pan)"]. Newsis, 7 March [online news item]. Retrieved 20 June 2020 from https:// mobile.newsis.com/view.html?ar_id=NISX20200306_0000945539\#_enliple.

Martin, A. J., Mansour, M., Anderson, M., Gibson, R., Liem, G. A. D., \& Sudmalis, D. (2013). The role of arts participation in students' academic and nonacademic outcomes: A longitudinal study of school, home, and community factors. Journal of Educational Psychology, 105(3), 709-727. https:// doi.org/10.1037/a0032795.

McCalliss, W. (2020). Massachusetts school district gets rid of art, music and PE teachers for coming school year. World Socialist Web Site, 30 May [online article]. Retrieved 10 July 2020 from https:// www.wsws.org/en/articles/2020/05/30/rand-m30.html.

Mervosh, S., Lu, D., \& Swales, V. (2020). See which states and cities have told residents to stay at home. The New York Times, 31 March [interactive online map]. Retrieved 23 June 2020 from https://www. nytimes.com/interactive/2020/us/coronavirus-stay-at-home-order.html.

Mikolajczak, M., Raes, M.-E., Avalosse, H., \& Roskam, I. (2018). Exhausted parents: sociodemographic, child-related, parent-related, parenting and family-functioning correlates of parental burnout. Journal of Child and Family Studies, 27(2), 602-614. https://doi.org/10.1007/s10826-017-0892-4.

Milkie, M. A., Nomaguchi, K. M., \& Denny, K. E. (2015). Does the amount of time mothers spend with children or adolescents matter? Journal of Marriage and Family, 77(2), 355-372. https://doi. org/10.1111/jomf.12170.

Mills, M. (2020). 13 Free virtual summer camps your kids will love. Parents Magazine, 26 May [online article]. Retrieved 20 June 2020 from https://www.parents.com/fun/activities/outdoor/free-virtualsummer-camps-2020/.

Moroni, G., Nicoletti, C., \& Tominey, E. (2020). Children's socio-emotional skills and the home environment during the COVID-19 crisis. VoxEU, 9 April [online article]. London: VoxEU, policy portal of the Centre for Economic Policy Research (CEPR). Retrieved 9 June 2020 from https://voxeu.org/ article/children-s-socio-emotional-skills-and-home-environment-during-covid-19-crisis.

Musick, K., Meier, A., \& Flood, S. (2016). How parents fare: Mothers' and fathers' subjective wellbeing in time with children. American Sociological Review, 81(5), 1069-1095. https://doi. org/10.1177/0003122416663917.

Nagel, B.D. (2020). Updated list of statewide school closures with closure dates. THE Journal, 11 May [online news item]. Retrieved 20 June2020 from https://thejournal.com/articles/2020/03/17/list-ofstates-shutting-down-all-their-schools-grows-to-36.aspx.

Nam, K. (2020). [Graphic News] COVID-19 helps toy sales. The Korea Herald, 20 February [online news item]. Retrieved 20 June 2020 from http://www.koreaherald.com/view.php?ud=2020022000 0931 
NPD (2020). At a time of social distancing, U.S. families turn to activity-based toys, books, and art supplies for the home, according to NPD. NPD, 2 April [online press release]. Port Washington, NY: The NPD Group, Inc. Retrieved 20 June 2020 from https:/www.npd.com/wps/portal/npd/us/news/ press-releases/2020/at-a-time-of-social-distancing-us-families-turn-to-activity-based-toys-books -and-art-supplies-for-the-home-according-to-npd/.

Nussbaum, M. C. (2010). Not for profit: Why democracy needs the humanities. Princeton, NJ: Princeton University Press.

Offer, S. (2013). Family time activities and adolescents' emotional well-being. Journal of Marriage and Family, 75(1), 26-41. https://doi.org/10.1111/j.1741-3737.2012.01025.x.

Oh, H. (2020). 학 교 못가 LI...장난 아니게 팔리는 장난감 [Toy sales surge as a result of school closure]. The Korea Economic Daily, 3 March [online article]. Retrieved 20 June 2020 from https:// www.hankyung.com/economy/article/202003032439i.

Park, H. (2020). "전임교수 가뭄, 앓는 미대생들..."순수 예술 죽고 있다" [Art school students suffering from 'insufficient full-time professors'... "The killing of fine art”]. Nocut News, 12 January [online news item]. Retrieved 10 July 2020 from https://www.nocutnews.co.kr/news/5271444.

Parker, K., Horowitz, J.M., \& Brown, A. (2020). About half of lower-income Americans report household job or wage loss due to COVID-19. Pew Research Center Social \& Demographic Trends, 21 April [online article]. Washington, DC: Pew Research Center. Retrieved 28 April 2020 from https ://www.pewsocialtrends.org/2020/04/21/about-half-of-lower-income-americans-report-householdjob-or-wage-loss-due-to-covid-19/.

Peele, H., \& Riser-Kositsky, M. (2020). Map: Coronavirus and school closures. Education Week, 6 March [interactive online map]. Retrieved 8 June 2020 from https://www.edweek.org/ew/section/multi media/map-coronavirus-and-school-closures.html.

Pew Research Center (2015). The American family today. Pew Research Center Social \& Demographic Trends, 17 December [online article]. Washington, DC: Pew Research Center. Retrieved 20 June 2020 from https://www.pewsocialtrends.org/2015/12/17/1-the-american-family-today/.

Rech, J. (2007). Discovering trends in software engineering with google trend. ACM SIGSOFT Software Engineering Notes, 32(2), 1-2. https://doi.org/10.1145/1234741.1234765.

Root-Bernstein, R. (2015). Arts and crafts as adjuncts to STEM education to foster creativity in gifted and talented students. Asia Pacific Education Review, 16(2), 203-212. https://doi.org/10.1007/s1256 4-015-9362-0.

Salisbury, S. (2020). Mayor Kenney calls for end to city arts agency, cutting \$4 million in cultural spending. The Philadelphia Inquirer, 1 May [online article]. Retrieved 2 July 2020 from https://www. inquirer.com/news/arts-culture-budget-cuts-elimination-20200501.html.

Save the Children (2020a). Children at risk of lasting psychological distress from coronavirus lockdown. Save the Children, 8 May [online article]. Retrieved 23 September 2020 from https://www.savet hechildren.net/news/\%E2\%80\%98children-risk-lasting-psychological-distress-coronavirus-lockd own $\%$ E2\%80\%99-save-children.

Save the Children (2020b). Bored, scared and confused: A new poll shows how COVID-19 is affecting children's mental health, but the news isn't all bad [webnews, 20 June] Fairfield, CT: Save the Children. Retrieved 20 June 2020 from https://web.archive.org/web/20200620215731/https://www.savet hechildren.org/us/charity-stories/survey-shows-coronavirus-impacts-on-childrens-emotional-menta 1-health.

Silver, G. (2020). How theater companies are innovating during the COVID-19 crisis. TodayTix Insider, 18 March [blog post]. Retrieved 20 June 2020 from https://www.todaytix.com/insider/nyc/posts/ how-theater-companies-are-innovating-during-the-covid-19-crisis.

Song, Y.-J. (2011). 한국인의 일 상생활 시간변화 - 부모의 교육수 준에 I다른 자 녀양육 시간. [Changes in parental time spent with children]. 한 국 인구학 [Korean Journal of Population Studies], 34(2), 45-64.

Statista (2020). South Korea: Impact of Coronavirus outbreak on online toy sales 2020. Statista, 29 May [online database]. New York, NY, Statista, Inc. Retrieved 20 June 2020 from https://www.statista. com/statistics/1101712/south-korea-impact-of-coronavirus-outbreak-on-online-toy-sales/.

Sullivan, A. (2001). Cultural capital and educational attainment. Sociology, 35(4), 893-912. https://doi. org/10.1017/S0038038501008938.

Swan, D.W. (2014). Children who visit museums have higher achievement in reading, math, and science. Institute of Museum and Library Services, 21 April [blog post]. Washington, DC: Institute of Museum and Library Services (IMLS). Retrieved 20 June 2020 from https://www.imls.gov/ blog/2014/04/children-who-visit-museums-have-higher-achievement-reading-math-and-science. 
U.S. Bureau of Labor Statistics (2018). Average hours per day parents spent caring for and helping household children as their main activity [online survey charts]. Retrieved 20 June 20 from https://www. bls.gov/charts/american-time-use/activity-by-parent.htm.

Verger, N.B., Urbanowicz, A., Shankland, R., \& McAloney-Kocaman, K. (2020). Coping in isolation: Predictors of individual and household risks and resilience against the COVID-19 pandemic. SSRN Scholarly Paper No. ID 3596094. Rochester, NY: Social Science Research Network. https://doi. org/10.2139/ssrn.3596094.

Villena-Roldan, B., \& Ríos-Aguilar, C. (2012). Causal effects of maternal time-investment on children's cognitive outcomes. Center for Applied Economics, Working Paper, 285. Santiago: University of Chile, Center for Applied Economics. http://doi.org/10.2139/ssrn.2255809.

Wang, G., Zhang, Y., Zhao, J., Zhang, J., \& Jiang, F. (2020). Mitigate the effects of home confinement on children during the COVID-19 outbreak. The Lancet, 395(10228), 945-947. https://doi.org/10.1016/ S0140-6736(20)30547-X.

Yun, H. (2013). 대전 대학들, 인문학 관련 학 과 잇단 폐지.통폐합 [Universities in Daejeon abolished and consolidated humanities departments]. KyungHyang News, 30 May [online news item]. Retrieved 10 July 2020 from http://news.khan.co.kr/kh_news/khan_art_view.html?artid=20130 $5302210565 \& \operatorname{code}=950301$.

Publisher's Note Springer Nature remains neutral with regard to jurisdictional claims in published maps and institutional affiliations.

Meera Choi is a PhD student in Sociology at Yale University in New Haven, CT, USA. Her research focuses on the intersection of family and culture.

Hannah Tessler is a PhD student in Sociology at Yale University in New Haven, CT, USA. Her research focuses on race, ethnicity and sociology of education.

Grace Kao is Chair and IBM Professor of Sociology and Faculty Director of Education Studies at Yale University in New Haven, CT, USA. She is the immediate past Vice President of the American Sociological Association. Her research focuses on race, ethnicity, immigrant adaptation, Asian Americans, adolescence and sociology of education. 